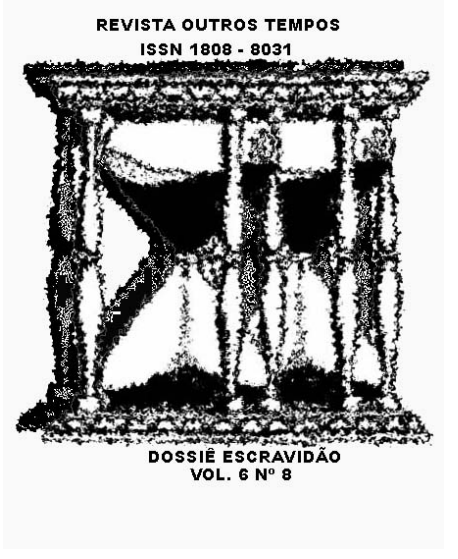

\title{
A EDUCAÇÃO DOS NEGROS NA SOCIEDADE ESCRAVISTA DO MARANHÃO PROVINCIAL
}

\author{
Dra. Mariléia dos Santos Cruz \\ Universidade Federal do Maranhão (UFMA) - Imperatriz. \\ euluena@hotmail.com
}

\section{RESUMO}

O presente trabalho revela particularidades importantes para compreensão das interdições históricas impostas a negros no tocante aos processos educacionais no contexto maranhense do século XIX. Enfoca a presença de alunos negros em escolas públicas, apesar dos obstáculos legais impostos contra o acesso de escravos ao ensino. $\mathrm{O}$ trabalho de pesquisa consistiu na identificação, transcrição e análise de fontes primárias produzidas no Maranhão do século XIX, as quais se encontram acondicionadas no Arquivo Público do Estado do Maranhão, e na Biblioteca Pública Benedito Leite.

Palavras-chave: Escolarização; Crianças Negras; Província Maranhense; Século XIX.

\begin{abstract}
This paper shows features important for understanding the historical bans imposed on blacks in regard to educational processes in maranhense context of the nineteenth century. Focuses on the presence of black students in public schools, despite the legal obstacles imposed on access to education of slaves. The research work was the identification, transcription and analysis of primary sources produced in Maranhão in the nineteenth century, which are stacked in the Public Archives of the State of Maranhão, and the Public Library Benedito Leite.
\end{abstract}

Keywords; Schooling; Black Children; Province Maranhão; nineteenth century. 


\section{Introdução}

O século XIX, sobretudo a partir da década de 30, tem sido injustamente caracterizado pela historiografia consagrada como a "idade das trevas" da educação brasileira (FARIA FILHO, 2007, p. 135). A ausência de legislações com abrangência a todo território do Império do Brasil, a partir do ato adicional de 1834, que atribuiu a cada província o dever de legislar e organizar o ensino primário e secundário no território imperial, certamente pode ser considerado o principal fator que influenciou nessa interpretação histórica sobre o período.

Os estudos que privilegiam análises de documentação provincial têm permitido perceber que o período imperial brasileiro não só pode ser caracterizado como um período frutífero para a compreensão da educação que se conhece hoje, como também permite a identificação da ocorrência de práticas escolares bastante semelhantes entre províncias diferentes, apesar da existência da autonomia legislativa entre uma e outra.

No Brasil, esse período representa o tempo da institucionalização da escola como instrumento de fortalecimento do papel do Estado, com suas estruturas de poder aglutinador em detrimento da articulação de estruturas locais de poder representados por fortunas familiares, com destaque para a autoridade patriarcal (FARIA FILHO, 2007, p. 135). Enquanto a educação servia para auto-reprodução do sistema patriarcal privilegiando a instrução masculina, não se podia fazer valer a autoridade do Estado, nem se vislumbrava a concretização dos ideais civilizatórios, que esbarravam em práticas contrárias, as quais se auto-reproduziam no universo cultural dos setores sociais desfavorecidos, a exemplo das mulheres, dos negros e índios, sobretudo dos pobres.

A escola do século XIX pode ser caracterizada como uma instituição que transitava entre a continuidade do ambiente doméstico e a consagração de um modelo institucional que substituía o papel desempenhado pela família na função de transmissão dos saberes. No tocante ao espaço físico, essas escolas se instituíam nas residências dos professores, na maioria das vezes sem um mobiliário específico para o desenvolvimento do ensino.

As escolas se diferenciavam de alguma forma da realidade conhecida pelo aluno em seu espaço familiar, devido aos seguintes fatores: existência de espaço determinado para o ensino; contato com uma rotina específica destinada à promoção da aprendizagem, que privilegiava o agrupamento de alunos de diferentes casas reunidos em espaço comum; aplicação de regras de convivência e uma rotina de estudo; além do emprego consciente de um método de instrução, por um indivíduo de alguma forma credenciado para a administração do ensino. 
A análise da documentação sobre instrução no século XIX no Maranhão revela que o período foi bastante frutífero para a consagração da escola como instituição específica, com o papel social definido no fortalecimento do Estado Moderno. O papel civilizatório assumido por esta instituição requeria a ampliação do acesso à instrução, o que, apesar das contradições, atingiu, mesmo que não de forma massiva e igualitária, diferentes setores sociais, abarcando, algumas vezes, inclusive pessoas negras. Essa perspectiva de análise contradiz afirmações elaboradas em estudos históricos da educação brasileira, que restringem as possibilidades de educação das crianças negras, no período escravista, apenas à “... violência do trabalho e nas formas de luta pela sobrevivência" (LOURO, 2007, p. 445).

No presente texto enfoca-se que no Maranhão, durante o século XIX, a educação dos negros não se concretizou apenas no sentido amplo do termo, onde o contexto escravista reproduzia-se pela educação para a submissão. Mas que, apesar da escravidão, os negros também eram influenciados por processos educativos que moldavam aspirações de civilidade, integração social e liberdade. Do ponto de vista da oferta de instrução, percebeu-se que a ação do Estado apresentava diferenciações profundas quando o favorecimento da instrução dos setores negros é comparado com o que se destinava aos outros grupos.

\section{Forros, ingênuos e escravos no contexto da escravidão}

Durante o século XIX, a sociedade imperial se caracterizava pela ascendência da legitimação dos saberes elementares (escrita, leitura e contagem), os quais se tornavam cada vez mais exigidos como condição básica para desempenho de diversas funções públicas e sociais.

A ascendência da funcionalidade dos saberes elementares, objeto da escolarização fez parte do processo de modernização do Brasil, cuja idéia de civilidade estivera centrada no esforço de adequar a vida cultural do Brasil aos valores e costumes das nações européias, consideradas, numa perspectiva hierárquica, o ápice do desenvolvimento humano. Em contrapartida, almejava-se atingir o maior distanciamento possível da cultura das nações consideradas inferiores, as quais eram identificadas como detentoras de um nível baixo de desenvolvimento que se localizava entre a selvageria e a barbárie.

Outro ideal corrente, que atraía adeptos no Brasil nesse contexto, era o do liberalismo. O discurso liberal procurava romper com a predestinação social, alegando que os méritos deveriam depender das capacidades individuais. Esse discurso no Brasil agradava à elite intelectual, mas pouco combinava com a realidade imperial que se alimentava do trabalho dos 
africanos e de seus descendentes escravizados. Mesmo assim, explicações racistas justificavam que a escravidão era uma conseqüência natural da incapacidade dos negros de se adequarem à cultura civilizada por não disporem de capacidades biológicas para alcançar méritos.

Neste período, o Brasil se encontrava em processo de decadência do sistema escravista e contava com uma população de negros bastante diversificada: em relação à origem africana, em relação à condição e, também, em relação a variações da cor da pele, produzidas pelo alto índice de miscigenação.

O fato de o contexto histórico se caracterizar pela presença de negros em condições diferenciadas, em relação à origem, à cor da pele, ao sexo e ao trabalho, só aumentava a complexidade das relações num sistema escravista. Assim como existiam no Brasil os negros nascidos em diversas regiões da África; participavam também do cenário social os nascidos no Brasil, muitos dos quais mestiços oriundos de uniões legítimas ou ilegítimas, segundo a visão da Igreja Católica. Enquanto havia negros escravizados, havia também aqueles denominados de forros, por terem conquistado a alforria, e os nascidos livres. Dependendo da sociedade, da composição racial da província, um quadro de maior ou menor interdição à integração do negro se efetivava.

Embora houvesse o desejo de separação dos brancos com os negros, o estado social de diversificação de situações em relação à condição possibilitou que o critério da cor da pele funcionasse como a principal forma de definir as distâncias sociais. Nem sempre era possível saber, à primeira vista, quem de fato se encontrava na condição de cativo, quando se tratava de um africano ladino ou um negro crioulo, principalmente nas regiões urbanas, onde as atividades econômicas executadas permitiam maior autonomia. Os ladinos, embora fossem africanos, conheciam a língua portuguesa, do mesmo modo que o crioulo, que era o negro nascido no Brasil. Também parecia difícil saber a diferença entre uma pessoa negra liberta por carta de alforria e outra nascida livre.

O termo livre era utilizado para designar os indivíduos que nasciam isentos da obrigação de trabalhar para usufruto de terceiros. Podiam ser identificadas assim tanto pessoas brancas quanto negras, contudo alguns documentos utilizam o termo ingênuo para caracterizar os negros filhos de libertos. Ou melhor, filho de mulher liberta, pois a herança da condição escrava ocorria pela maternidade e não pela paternidade.

O termo ingênuo é muitas vezes interpretado em textos históricos para identificações ocorridas após a Lei do Rio Branco, conhecida como Lei do Ventre Livre (1871), quando é empregada para mencionar as crianças nascidas de mulheres cativas após a vigência da lei. 
Contudo, a documentação em período anterior sugere que esse vocábulo tenha sido utilizado em sentido mais amplo, para identificação dos negros nascidos livres, ou seja, para identificar os sujeitos correspondentes à segunda geração do liberto. Esse sentido é tomado do termo jurídico empregado no mundo romano (AZEVEDO, 1999, p. 252), o que não deve ser interpretado como algo alheio à realidade brasileira da época, uma vez que, apesar de o Brasil se respaldar nas Ordenações Filipinas, ocorria que, em casos omissos, recorria-se às leis romanas, de onde haviam se originado.

Embora que atualmente tenhamos a tendência à representação histórico dos negros como um único grupo prejudicado pelas relações de escravidão, o fato é que a população afrodescendente embora unida pelo tratamento diferenciado numa sociedade que atribuía privilégios respaldando-se em valores racistas, se constituía como um grupo bastante diversificado. Tal diversificação imprimia nas relações sociais maiores ou menores possibilidades de integração social e alimentava, entre o segmento, interesses diferenciados e muitas vezes até contraditórios.

\section{Sobre o direito à instrução pública na província maranhense}

No contexto do Maranhão observam-se iniciativas que visavam a favorecer a ampliação da escolarização, contemplando setores desfavorecidos socialmente, denominados, à época, "todas as classes de cidadãos"1. Em apreciação geral da documentação histórica referente à instrução pública, foi possível identificar ações governamentais envolvendo emprego de recursos públicos em benefício de crianças indígenas, portadores de deficiências auditivas, migrantes cearenses e imigrantes estrangeiros.

A lei $\mathrm{n}^{\circ} 408$, de 18 de julho de 1856, determinava que três vagas da Casa dos Educandos Artífices ${ }^{2}$ deveriam ser ocupadas por meninos indígenas, propostos pelo diretor geral dos indígenas (artigo $2^{\circ}$, Coleção de leis, 1856, p. 6).

Com semelhante teor, a correspondência do Presidente da Província, de 9 de outubro de 1867, instruiu o diretor do Asilo de Santa Teresa ${ }^{3}$ a admitir a índia menor Severa “...

\footnotetext{
${ }^{1}$ Termo utilizado na época como referência aos setores empobrecidos que compunham as camadas populares.

${ }^{2}$ A Escola de Educandos Artífices foi criada em virtude da lei $\mathrm{n}^{\circ} 105$, de 23 de agosto de 1841, visando a atender meninos pobres e desvalidos. No decorrer dos seus 48 anos de existência, essa escola desfrutava prestígio e admiração da sociedade maranhense. Oferecia formação pautada em "primeiras letras e princípios religiosos, o ensino de um ofício mecânico e o exercício militar necessário à Guarda Nacional" (art. 3, Regulamento de 2 de dezembro de 1841).

${ }^{3}$ Esta escola feminina foi criada em 16 de janeiro de 1855 e inaugurada em 14 de março do mesmo ano, em uma casa situada no Largo dos Remédios. Esta casa, destinada ao amparo de desvalidas, iniciou suas atividades com 40 pensionistas da província, evoluiu para 50 em 1856, e para 60 em 1864 (MARQUES, 1970, p. 95-96). O objetivo principal do Asilo de Santa Teresa era acolher meninas pobres da província e educá-las para o emprego
} 
mediante pensão estipulada para as pensionistas particulares (...) paga pelo Tesouro Provincial por conta da verba de catequese e civilização dos índios" (Livro $\mathrm{n}^{\circ} 101$, fl. 17, doc. 138). Severa consta como aluna particular do Asilo de Santa Teresa descrita em relação de alunas no ano de 1868. Neste documento, a educanda é citada pelo diretor da escola como “... mandada admitir por portaria do Governo de 8 de outubro de 1867 mediante a pensão estipulada para pensionistas particulares até poder entrar como pensionista da província efetiva nas primeiras vagas ...” (Relação das educandas do Asilo de Santa Teresa, 13 de maio de 1868. Secretaria do Governo. Diretor do Asilo de Santa Teresa/ Presidente da Província, cx. 1855-1870). A reserva de vagas em escolas concorridas do Maranhão provincial a crianças indígenas permite contradizer a crença de que a educação indígena era vedada nas escolas públicas do período, como afirma Louro (LOURO, 2007, p. 445).

Outra lei que traduzia a implementação de políticas educativas direcionadas a contemplar setores sociais desfavorecidos socialmente é a de $\mathrm{n}^{\circ} 1071$, de 04 de julho de 1874 , a qual autorizava o governo a remeter dois ou três surdos-mudos para o instituto do Rio de Janeiro. Anteriormente a esta lei, observam-se apenas proibições ao direito de admissão em escolas públicas aos portadores de deficiências.

Em outras situações existiram leis voltadas a criar clima favorável para a integração de imigrantes, conforme ocorreu em relação aos europeus incentivados à prestação de serviços e à colonização do Brasil, e em relação aos cearenses vítimas da seca nordestina.

Em 8 de maio de 1855, o governo provincial firmou contrato com Casa Vergueiro \& Companhia, regulando as condições para o engajamento de, no mínimo, 150 colonos em famílias da Alemanha, Suíça ou Sardenha, sendo estes agricultores e artífices. Dentre as condições estabelecidas, ficou a cargo da província: o pagamento das passagens dos colonos; morada e sustento até que fossem empregados; socorro aos enfermos; data de terras de cem braças para os solteiros, de cento e cinqüenta para famílias de até três pessoas e duzentas braças a famílias mais numerosas. Além dos benefícios citados acima, no parágrafo $6^{\circ}$ fícou determinada a responsabilidade do governo provincial na oferta de instrução primária nas escolas de primeiras letras para os filhos dos colonos empregados nas obras públicas (Coleção de Leis, regulamentos e outros atos do governo, 1856, p. 150-152).

Outro dado interessante que evidencia a existência de uma preocupação por parte do governo de, além de garantir aos imigrantes uma infra-estrutura básica, firmar o compromisso

doméstico, o que diferenciava o papel desta instituição em relação a outros asilos femininos que existiram no Brasil, que não tinham a função profissionalizante. 
com a educação das novas gerações oriundas destas famílias, aparece no texto da lei $n^{\circ} .381$, de 30 de junho de 1855, relativa à criação da cadeira de primeiras letras na colônia Santa Thereza (Coleção de Leis, 1855, p. 44). Esta colônia foi fundada em 1855 com 150 colonos, na região de Cururupu, e um ano depois já não existia.

A colônia Santa Thereza não foi à única a ser contemplada pela criação de cadeira de primeiras letras, pois houve também a Colônia Santa Isabel, criada no Maranhão dentro da política de colonização estrangeira, que também foi privilegiada com a medida. Essa colônia foi criada em 1853, e dentre as demais, foi à única que realmente prosperou no Maranhão. Em 1862, possuía uma aula de primeiras letras, freqüentada por 31 alunos (MARQUES, 1970, p. 204).

No caso dos cearenses vítimas da seca nordestina, de 1877, ocorreu a história peculiar da formação de uma colônia destinada a reunir 800 famílias do Ceará que viviam em situação de indigência nas terras maranhenses. A colônia foi nomeada de Colônia Prado, criada pelo Presidente da Província Graciliano Aristides do Prado Pimentel, no local onde se localizava o quilombo Limoeiro.

O quilombo Limoeiro sofreu invasão e saque, em 1878. Parte de sua população foi capturada pelas tropas do governo enquanto outra parte, a maioria, foi dispersa pelas matas (APEM, 1992, p. 9). O fato se deu por ordem governamental que instruiu as forças policiais a capturar os quilombolas e aproveitar as terras consideradas “... de extraordinária uberdade para acomodar o maior número possível de retirantes cearenses, que encontrarão roças e casas abandonadas...", conforme correspondência de 28 de maio de 1878 (APEM, 1992, p. 79).

Dentre dez itens de instrução do Presidente da Província dirigidos ao capitão no ofício de 28 de maio de 1878, o último colocava a escola como uma instituição tão importante quanto à igreja em seu papel civilizador, e refletia a tentativa de disseminação do acesso à escolarização às populações empobrecidas. Textualmente ordenava-se a "construir um edifício modesto, que sirva de templo provisório onde os colonos assistam os atos religiosos e bem assim outro para servir de escola pública (...) a fim de serem contratados um capelão e um professor" (APEM, 1992, p. 81).

Além destes benefícios destinados a setores pobres da população em relação à instrução elementar houve, também, medidas governamentais em favor da continuidade da educação de jovens provenientes de setores providos de recursos econômicos, por meio de verbas públicas direcionadas ao custeio de estudos no exterior. No Regulamento de 10 de dezembro de 1858, que fundou a escola dos Aprendizes Agrícolas, ficou determinado que o governo devesse nomear: 
... três moços de reconhecida aptidão e suficientemente preparados para seguir com proveito, e as expensas da província, o curso de Agricultura em algumas das mais acreditadas escolas da Alemanha, ou América do Norte, sujeitando-se por um contrato a vir ensinar no estabelecimento o curso das matérias que tiverem aprendidos, o que fizerem parte do programa, mediante uma gratificação anual..." (Regulamento de 10 de dezembro de 1858, Art. 10, Coleção dos regulamentos e outros atos do governo, p. 14).

No ano de 1861, por meio da lei $\mathrm{n}^{\circ}$. 624, registrada no livro de atas da Assembléia Legislativa Provincial, em 15 de outubro, autorizavam-se três estudantes: João Duarte Peixoto Franco de Sá, Luís Raimundo Silva Brito e Theodoro Airton Pereira de Castro a preencherem as vagas para estudar agricultura na Europa.

Em 1863, por meio da lei $\mathrm{n}^{\circ}$. 666, de 7 de julho, o Presidente da Província foi autorizado a mandar estudar desenho e pintura na Europa os jovens Horácio Tribuzi e Joaquim Belfort Sabino. O primeiro na Itália, e o segundo na Inglaterra, visando à formação teórica e prática das artes mecânicas necessárias à profissão de engenheiro prático. Os estudantes pensionistas da província no exterior seriam beneficiados com pagamento de um conto de réis anuais, por espaço de três anos, com despesas de viagens, sendo exigido em contrapartida que eles servissem à província por igual espaço de tempo, quando retornassem (Coleção de leis, decretos e resoluções da província do Maranhão, 1863). Em 1866, uma lei, com semelhante teor, foi promulgada, sob o $\mathrm{n}^{\circ}$. 769, a qual autorizava Francisco Peixoto Franco de Sá a estudar desenho e pintura nas escolas da Europa (Coleção de leis, 1866).

Apesar da existência de medidas governamentais direcionadas a propiciar instrução elementar a setores públicos socialmente desfavorecidos, bem como ocorreu também com o financiamento para a formação de jovens no exterior, não se observou em nenhum momento, na documentação analisada, qualquer referência quanto à necessidade de favorecer a negros, como categoria específica, no processo de escolarização. Considerando que a segunda metade do século XIX foi marcada pelo clima intenso de embates teóricos e de ações em favor do fim da escravidão em todo o Brasil, poder-se-ia esperar que, além das medidas efetivadas que previam a libertação gradual dos escravos, existissem medidas visando a adequação população negra aos valores civilizatórios almejados para época. Papel que a escola poderia desempenhar com suficiente desenvoltura, beneficiando não só os libertos em razão das leis que faziam parte do processo que previa a conquista gradual da libertação, mas principalmente, aqueles que já haviam nascido livres.

As medidas tomadas pelo governo provincial caracterizam a vigência de um discurso cuja educação era colocada como instrumento indispensável para efetivação de um projeto 
civilizatório para a sociedade maranhense. Análise do texto do regulamento da instrução pública de 1855 permite detectar a articulação do discurso civilizatório embutido nas intenções governamentais dirigidas para o campo escolar.

$\mathrm{Na}$ reforma da instrução pública de 1855, determinava-se que: “os pais, tutores, curadores ou protetores, que tiverem em sua companhia meninos maiores de 7 anos sem impedimento físico ou moral, e não lhes derem o ensino pelo menos do primeiro grau, incorrerão na multa de $10 \$ 000$ à $60 \$ 000$ reis..." (Regulamento de 02 de fevereiro de 1855, artigo 36).

Observa-se que naquela época já se fazia vigente o princípio da obrigatoriedade do ensino básico, embora que a responsabilidade de efetivação do acesso das crianças não se constituía enquanto um dever do Estado, mas sim dos responsáveis pelas crianças maiores de sete anos. Sendo assim, o crime especificado no texto legal não deveria ser considerado se o responsável fosse "notoriamente indigente" (artigo $8^{\circ}$ ). O que significa dizer que o direito à instrução foi disfarçado de obrigatoriedade de ensino, ficando o seu cumprimento a cargo apenas das famílias detentoras de poder econômico. O que de fato ocorria era que o texto da lei se referia ao direito dos pobres de terem liberdade de permanecer sem escolarização.

O crime especificado no artigo 36 não se constituía como tal em caso de crianças com "impedimento físico e moral". Enquanto é possível interpretar o que a lei retratava ao se referir às "crianças com impedimento físico" parece extremamente subjetiva a identificação dos meninos com impedimento moral. Seria esta uma forma de manifestar alguma limitação ao acesso à escola por negros, tendo em vista que a ideologia do racismo pregava a inferioridade moral dos africanos e seus descendentes?

No artigo 41 do mesmo Regulamento, a restrição às possibilidades escolares para negros tornou-se mais acentuada ao se declarar, textualmente, que os escravos não poderiam ser "admitidos à matrícula" 4 .

Considerando que a ideologia escravista concebia o escravizado como incapacitado para uma vida social, nos modelos instituídos pelas civilizações de origem européia, por que haveria necessidade de proibir a matrícula a esse segmento? Certamente em razão da necessidade de coibir a ação dos que arriscassem a introduzi-los em processos de aprendizagem, negando assim as ideologias anunciadas. Ou, certamente, para coibir que filhos bastardos de senhores com suas escravas ocupassem os bancos escolares.

\footnotetext{
4 “Os menores de 5 anos e maiores de 15”," os que padecem de moléstias contagiosas", "os que não tiverem sido vacinados" e "os escravos" fazem parte do grupo definido pelo Regulamento da Instrução Pública da Província do Maranhão de 1855 como os que "não poderão ser admitidos à matrícula" (grifos nossos).
} 
Em 1855 o presidente provincial maranhense era Eduardo Olímpio Martins. Esse presidente foi considerado um administrador comprometido com a instrução pública voltada para o atendimento, segundo as suas próprias palavras, "a todas as classes de cidadãos". No governo de Eduardo Olímpio Martins foram aplicadas algumas regras de organização geral da instrução pública, fazendo-se perceber pela primeira vez a idéia de um sistema de ensino no Maranhão. Citado por Viveiros (1953), Eduardo Olímpio Martins descreveu as medidas tomadas na sua administração:

\begin{abstract}
$\mathrm{Na}$ reforma, a que procedi, tive principalmente em vista, como condição de melhoramento: a conveniente inspeção e fiscalização do ensino; organização e regularização dos diversos estabelecimentos de instrução; as condições, matéria e propagação da mesma; as habilitações e exames para o magistério; a repressão das omissões e a distribuição da recompensas no exercício das funções magistrais; a admissão, freqüência e aproveitamento dos alunos; imposição de multa aos pais, tutores e protetores negligentes em mandar instruir seus filhos, pupilos e protegidos; o fornecimento de material indispensável para a instrução mantida pelo Estado; o estabelecimento das taxas para melhorá-la no porvir; e, finalmente, as mais providências, que me parecem adequadas para uniformizá-las em todos os seus diferentes círculos ou delegacias, da respectiva inspeção, e estendê-la a todas as classes de cidadãos, ainda os mais pobres e desvalidos (VIVEIROS, 1953, p. 20).
\end{abstract}

Como se observa, o governo de Eduardo Olímpio Martins assumiu o discurso de contemplar os mais pobres com ações voltadas para a instrução pública, o que demonstra ao defender a ampliação da instrução a "todas as classes de cidadãos". . Contudo, escravizados não estavam incluídos no universo dos cidadãos, uma vez que constitucionalmente não dispunham de cidadania. Esse fato demonstra que as políticas públicas no âmbito educacional, mesmo aquelas que visavam a alcançar as camadas populares, foram implementadas com mecanismos de exclusões a camadas negras da população escravizada (CRUZ, 2009, p.87).

\title{
A instrução de negros na província do Maranhão
}

Conforme Cruz (2009, p. 116) as interdições à instrução de negros que vigoraram na província maranhense se caracterizam tanto por vetos no plano legislativo, como também por práticas de exclusão de alunos tomando como critério a cor escura acentuada da pele ou a condição escrava.

Embora que após a lei Rio Branco (1871) tenha se observado que a legislação provincial maranhense tenha suprimido a referência ao veto da instrução para escravos, ainda

\footnotetext{
${ }^{5}$ O termo "todas as classes de cidadãos" foi utilizado como referência ao compromisso do Estado em contemplar as crianças pobres. Com esta mesma conotação foi utilizado o termo "camadas inferiores da sociedade" no contexto do início do século XIX, no caso de Minas Gerais, conforme Faria Filho (2007, p. 137).
} 
não foi nesse momento que a educação dos negros foi contemplada com políticas específicas. O direito à educação pelos filhos do ventre livre só se constituía como dever do Estado quando da inexistência de associações autorizadas pelo governo voltadas para essa função (CRUZ, 2009, p. 89).

Nesse contexto era comum a existência de associações civis que assumiam o papel manumissor, embora que não demonstrassem interesse em se responsabilizar pela educação dos ingênuos. Além das irmandades que passaram a alforriar escravos durante a comemoração do dia dos seus santos de devoção, também surgiram entidades comprometidas especificamente com a compra de alforria. O clima pró-liberdade via compra de alforria que tanto influenciava entidades filantrópicas foi estimulado pela lei 2040, de 1871.

Por meio do fundo de emancipação, as entidades podiam contar com recursos sob a forma de cotas anuais disponíveis para libertação em cada província. Algumas entidades assumiam assim o papel definido pela lei Rio Branco de promover a libertação de alguns escravos.

A Sociedade Manumissora Vinte e Oito de Julho foi uma das entidades maranhenses que representou bem o que estava disposto na lei do Ventre Livre. Foi criada no ano de 1869, mas teve seu estatuto aprovado pela presidência da província apenas em 1872, portanto um ano após a Lei do Ventre Livre. Segundo o estatuto, esta sociedade tinha “ ... por fim libertar o maior número de escravas de menor idade, não adultas" (Art. $1^{\circ}$ ), podendo também alforriar escravos quando "receber subvenções dos cofres públicos". Nos artigos 47, 48 e 49 fícou determinado que:

Art. 47. (...) se os meios (...) permitirem, fundará o mais próximo que for possível da capital uma colônia agrícola sob a denominação de: _ Colônia 28 de Julho_.

Art. 48. A sociedade, neste caso, requererá ao governo imperial uma subvenção em favor da colônia, e ao Governo provincial, a fundação d’uma escola, no sentido do artigo seguinte:

Art 49. A escola da Colônia será de facto uma "escola practica agrícola" podendo admitir discípulos.

Não tivemos conhecimento da existência da Colônia Vinte e Oito de Julho, como também, não identificamos nenhuma lei provincial voltada para a fundação de outra escola de prática agrícola que não tenha sido a Escola Prática de Aprendizes Agrícolas ${ }^{6}$, que existiu em período anterior sob a responsabilidade do governo provincial. A idéia foi oportuna e afinada com o disposto na lei Rio Branco, tanto no que diz respeito à educação dos ingênuos, que

\footnotetext{
${ }^{6}$ Criada pela Lei Provincial 446 no ano de 1856, teve sua regulamentação aprovada em 10 de dezembro de 1858 , mas só foi inaugurada em 07 de abril de 1859. A escola do Cutim, como era conhecida pela localização à margem do rio que tinha o mesmo nome, visava ao ensino prático e teórico da profissão de lavrador a alunos indigentes (Regulamento de 10.12.1858, p. 15), ocupando-se também de ministrar o ensino de primeiras letras.
} 
deveria ficar a cargo de associações, quanto à possibilidade de essas associações receberem recursos do fundo de emancipação para promoverem a manumissão.

Vale ressaltar que a prática de alforriar assumida pelas associações caritativas beneficiou principalmente escravas de menor idade. Schwartz (2005) revela que o número de mulheres alforriadas era o dobro do de homens, principalmente quando a mulher atingia os treze anos (p. 275). Embora as mulheres fossem a minoria entre a população cativa, correspondiam à maioria a adquirir alforria (VAINFAS, 2002, p. 34). Tal fato evidencia a possibilidade de haver uma demanda de libertas de menor idade, disponíveis à frequiência escolar.

A prática de libertar meninas de menor idade pela compra de alforria como uma ação de benevolência social se inicia no Maranhão no ano de 1867 , pela ocasião da festa do Protetor da Irmandade do Glorioso São Benedito. Naquele ano, a irmandade promoveu através da obtenção de esmolas, a alforria de 15 meninas. No ano seguinte, em razão da mesma solenidade, alforriaram-se 36 meninas, atingindo até o ano de 1872 um total de 160 crianças libertas (Publicador Maranhense, 9 de abril de 1872).

Seguindo a mesma tendência assumida pela Irmandade do Glorioso São Benedito é que a Sociedade Manumissora 28 de Julho alforriou, até o ano de 1871, 29 escravos, sendo que, deste total, vinte pessoas eram do sexo feminino, conforme a entidade relatou ao presidente da província em 04 de dezembro de 1871 (Relatório da Sociedade Manumissora Vinte e Oito de Julho em 04 de dezembro de 1871, APEM, avulsos, Cx. 1869-1889).

As entidades que assumiam o papel manumissor davam preferência à alforria de meninas, isto porque eram entidades que almejavam a libertação da escravidão no Brasil de forma "pacífica e gradual", sem prejuízo dos senhores. Como havia maior necessidade do braço masculino para manutenção da ordem escravista, as mulheres eram menos essenciais em quantidade no contexto da escravidão e também representavam “...fontes de famílias no futuro da sociedade"(Publicador Maranhense, 9 de abril de 1872,p. 2). Em geral, as mulheres eram preferidas na condição de escravas em relação aos homens quando o objetivo do senhor era submetê-las à prostituição (FIGUEIREDO, 2007, p. 157).

Enquanto algumas entidades civis se voltaram a arrecadar recursos públicos e privados visando à compra da alforria de escravos, nenhuma ação foi identificada neste sentido com o objetivo de promover a educação dos ingênuos. A referência encontrada neste sentido retrata justamente a dificuldade de uma entidade manumissora em assumir essa função educativa, por considerar a atividade de educar ingênuos, algo oneroso (CRUZ, 2009, p. 90). 


\section{Crianças negras em aulas de primeiras letras}

Com a lei de 15 de outubro de 1827, que determinava a criação de escolas de primeiras letras destinadas à instrução elementar da população livre nas vilas mais povoadas das províncias (VAINFAS, 2002, p. 383), houve aumento das possibilidades da instrução de negros no Brasil, principalmente em províncias como Maranhão, onde a população negra era significativa. $O$ aumento significativo da população negra, especialmente a mestiça, dificultava que as escolas de primeiras letras procedessem de forma muito seletiva. Outro fator importante é que os professores de primeiras letras precisavam de um número elevado de discípulos que justificasse o recebimento dos seus salários.

Segundo a lei 267 de 17 de dezembro de 1849, os professores públicos deveriam apresentar mapas que comprovassem o número de alunos. De acordo com a lei, os professores que possuíam de 10 a 39 alunos receberiam 300 mil reis de salário e gratificação adicional de três mil reis por cada aluno. De 40 a 79 alunos, o salário deveria corresponder a 450 mil reis e mais o adicional. De 80 a 160, o vencimento chegaria em 600 mil reis e gratificação. Com menos de 10 alunos, o professor não era considerado em exercício.

A observação de documentação sobre instrução pública no acervo do APEM permite constatar que os itens que constam nos documentos elaborados pelos professores não seguiam um padrão definido na exposição dos dados. Nesses documentos há ausência de informações que indique cor ou condição. Apesar desse fato havia a possibilidade de que meninos negros, mesmo não recebendo a devida identificação na documentação estivessem entre os outros discípulos em aulas espalhadas pelo Maranhão provincial.

Apesar de a maioria dos mapas não respeitarem um padrão definido na exposição dos dados sobre as turmas, destacam-se os mapas elaborados pela Professora da Vila de Viana, a Senhora Anna Clara Pereira. Os mapas elaborados pela professora de Viana diferenciam-se completamente dos demais observados. É que, além do nome das suas alunas, a professora destacava a categoria "qualidades", a qual preenchia registrando a cor da pele das alunas. Em um mapa referente ao mês de agosto e assinado com a data de 2 de setembro de 1841, há um total de 41 alunas, dentre as quais uma é indicada como "preta livre", Joana Baptista, e a outras duas são indicadas com a caracterização de "parda", são Margarida Lionidia de Jesus e Francisca Maria de Jesus. Há nesta lista outra menina também chamada de Francisca Maria de Jesus, qualificada como branca.

O segundo mapa referente à turma da professora Anna Clara Pereira, corresponde ao mês de setembro e foi assinado no dia 20 de outubro. Neste documento, o número de alunas 
aparece reduzido a 40, permanecem listadas Margarida Lionidia de Jesus e Joana Baptista, e suas atribuições correspondentes, parda e preta livre. Contudo, desta vez as duas meninas chamadas Francisca Maria de Jesus foram identificadas como "brancas".

Consultando o mapa enviado pela mesma professora durante o ano de 1840, observa-se que o item que utiliza para identificar as alunas pela cor não aparece. Em compensação, registra ao lado dos nomes de suas alunas as respectivas idades, data de entrada na aula e o desempenho. Neste mapa, referente a 16 de outubro de 1840, Francisca Maria de Jesus possui 10 anos, é natural de Viana, entrou para a turma em 09 de março de 1939. Registra-se que a aluna "lê, coze, faz renda, está em diminuir, e pouco freqüenta a aula". As demais meninas discriminadas como "parda" e "preta livre" não estão registradas nesse documento.

Os indícios que a documentação aponta permitem inferir que a professora tinha dificuldade em classificar as alunas pela cor da pele. Em caso de Maria Francisca de Jesus ser irmã de Margarida Lionidia de Jesus, não se pode descartar a hipótese de que, como mestiças, uma fosse mais escura que a outra, um fato que poderia influenciar, a princípio, uma classificação diferenciada.

Outro indício de que aulas de primeiras letras instituídas por várias vilas no interior do Maranhão, consistiram em importantes espaços para o acesso à escolarização de crianças negras (especialmente, os mestiços filhos de libertos) está na documentação sobre a Colônia Militar do Gurupi.

A Colônia Militar São Pedro do Gurupi, conhecida como Colônia do Gurupi, foi autorizada, pelo presidente Eduardo Olímpio Machado, em 26 de novembro de 1853, visando, além de povoar a região considerada muito fértil, situada às margens do Rio Gurupi, entre o Maranhão e o Pará, a servir de apóio para as ações de controle da emergência de quilombos naquela região. No ano de 1855, o diretor da Colônia enviou ao Presidente da Província uma relação de moradores da localidade composta por 51 nomes, todos identificados como livres e identificados pela cor da pele.

A identificação da cor da pele expressa nesta relação demonstra que apenas 4 pessoas eram brancas, 1 era preta e as demais mestiças, distribuídas da seguinte forma: 3 cafuzas, 8 mamelucas, 11 caboclas e 24 mulatas. Dentre o universo de moradores 18 eram crianças, das quais 13 faziam parte da turma de primeiras letras iniciada em 1855.

A aula de primeiras letras se iniciou na colônia em 10 de maio de 1855, com 13 alunos, embora o número de crianças que existiam no lugar fosse superior. Provavelmente, a idade menor de 7 anos é o que impossibilitava que 4 crianças freqüentassem estas aulas, ficando incógnito o motivo que impedia que a turma tivesse 14 alunos. Os dados referentes à 
formação da turma para aula de primeiras letras desta colônia militar, destinada ao controle rigoroso da emergência de quilombos, com atuação decisiva para destruição de vários mocambos durante todo o século, causam surpresa quando se identifica que os meninos e meninas que compunham a turma eram, majoritariamente, mestiços (mulatos, caboclos e mamelucos).

No exemplo da Colônia do Gurupi, uma localidade onde a população se constituía por maioria mestiça se observa a impossibilidade de restringir a participação escolar nas aulas de primeiras letras apenas a crianças brancas. Dessa mesma forma, a diversidade racial do Maranhão se refletia em outras vilas cuja população de escravos, libertos e seus descendentes superavam à branca. Neste contexto, até mesmo escravos podiam, naquela época, passar como se livres fossem, e desta representar mais um número, em salas de aula de professores ávidos por atingir o número de alunos exigido pelo Estado para efetivação dos salários.

Em apreciação da documentação sobre a instrução pública no Maranhão, identifica-se uma série de mapas de turmas das vilas onde havia aulas de primeiras letras os quais, embora praticamente não se evidencie a cor da pele dos alunos, apresenta outros indícios que permitem inferir sobre a presença de negros nessas escolas. Os indícios consistem na origem natural de muitos alunos e na ausência de sobrenomes.

Nesses documentos há alunos cuja filiação é indicada como incógnita quanto ao registro do nome do pai e, algumas vezes, apresenta-se apenas nome de mãe, indicando que o indivíduo é resultante de união ilegítima, denominado naquela época, como filho natural. Um exemplo tal enfoque consiste no mapa dos alunos da escola de primeiras letras na freguesia de Nossa Senhora da Victória, enviado às autoridades em 5 de abril do ano de 1841. Neste documento, o professor João Francisco da Cruz apresentou uma relação de 25 alunos, sendo 13 de filiação incógnita e 12 cujo nome do pai consta ao lado do nome do aluno.

A ausência de sobrenomes representa indício de origem negra destas crianças, pois durante a escravidão era comum ao escravo só possuir o primeiro nome, herdando do senhor algumas vezes o sobrenome no ato da alforria. Além do registro do nome das crianças com ausência de sobrenomes, havia também, em algumas relações nominais, a indicação de paternidade como incógnita, ou acompanhados pelo nome da mãe. Esses elementos indicam que havia criança proveniente de uniões ilegítimas, de descendência africana, mesmo que nem sempre devidamente identificadas como tal nas turmas de primeiras letras do Maranhão.

A relação entre a ausência de sobrenomes e a procedência escrava dos sujeitos é confirmada quando se observa o Primeiro Caderno do Recenseamento da População da Cidade de São Luís do Maranhão, em 1855. Neste documento, em que as pessoas são 
identificadas pelo endereço, cor, condição, sexo, profissão e idade, podem-se constatar a relação direta entre os de cor preta e a ausência de sobrenomes neste livro (códice 1701). A título de exemplo, apresentam-se informações obtidas pela análise do primeiro quarteirão. De um total de 46 recenseados, 35 apresentavam apenas o primeiro nome, sendo 23 pretos, 12 mestiços identificados como pardos, mulatos e cafuzos. Apenas um apresentava prenome composto, era a parda Maria Martha, e 10 indivíduos apresentam nomes completos com nome de batismo e sobrenome, destes, 01 era negro, 02 eram pardos e 08 eram brancos.

A mesma tendência permanece em todo o documento, o que permite inferir haver uma relação direta entre a ausência de sobrenome e a origem negra dos sujeitos que aparecem na documentação maranhense do século XIX. Não se identificou um só sujeito branco que possuísse apenas o prenome, mas se observou que havia pretos, e principalmente pardos, que possuíam nomes completos. Esse fato permite a confirmação da hipótese de que os sujeitos que não tinham sobrenomes eram descendentes de africanos.

\section{Considerações finais}

Durante o século XIX, quando os discursos e as preocupações das elites estiveram voltados para o desafio de tornar o Brasil uma nação civilizada, o negro foi considerado ser incapacitado para a integração no contexto histórico almejado.

Conforme indica a documentação sobre instrução pública no Maranhão existiram, durante o século XIX um conjunto de leis provinciais direcionadas ao financiamento público da educação de indígenas, colonos europeus, colonos cearense, deficientes auditivos e jovens provenientes de famílias brancas detentoras de poder aquisitivo. Tal fato sugere que a prática de beneficiar setores sociais com recursos públicos, sobretudo no campo da educação, não consiste num evento recente, embora que os negros não tenham sido beneficiários dessas ações governamentais como categoria particular como ocorreu com outros setores sociais.

Contudo, apesar do contexto escravista que impunha obstáculos legais à integração social dos negros, sobretudo dos escravizados, a exemplo da proibição da escolarização de crianças cativas, não se pode afirmar que todos os descendentes de africanos que viveram no período tenham sido excluídos do acesso de níveis de instrução. Antes, pode-se concluir que especialmente os negros libertos e os mestiços, bem como seus descendentes, estiveram inseridos em turmas de primeiras letras na província maranhense, a qual era constituída por uma população massivamente negra, embora que nem sempre estejam devidamente identificados pela cor nos mapas de instrução pública, elaborados pelos professores da época. 
Observa-se que, no Maranhão, a educação dos negros não se concretizou apenas no sentido amplo do termo, onde o contexto escravista reproduzia-se pela educação para a submissão. Mas que, apesar da escravidão, os negros também eram influenciados por processos educativos que moldavam aspirações de civilidade, integração social e liberdade. 


\section{Referências}

APEM, Arquivo Público do Estado do Maranhão A invasão do Quilombo Limoeiro. São Luís, SIOGE, Edições APEM, 1992.

AZEVEDO, Antonio Carlos do. Dicionário de nomes, termos e conceitos históricos. $3^{\mathrm{a}}$ ed. Ampliada e atualizada. Rio de Janeiro: Nova fronteira, 1999.

BRASIL, Constituição Brasileira do Império do Brasil. (1824). Disponível em www.unificado.com.br/calendario/03/int-const.htm.

Lei 2040 de 28 de setembro de 1871. Declara de condição livre os filhos de mulher escrava que nascerem desde a data desta lei, libertos os escravos da Nação e outros, e providencia sobre a criação e tratamento daqueles filhos menores e sobre a libertação anual de escravos, como nela se declara. Disponível em: www.prr1.mpf.gov/nucleos/nucleocriminal/trabalho/lei2040-28-set-1871-lei-do-ventre-livre.htm-24k. Acesso em: 20 de jan. 2007.

CRUZ, Mariléia dos Santos. Escravos, forros e ingênuos em processos educacionais e civilizatórios na sociedade escravista do Maranhão no século XIX. Tese defendida pela Universidade Estadual Paulista-FCL- Araraquara, 2008.

Políticas de ações negativas e aspirações de famílias negras pelo acesso à escolarização no Maranhão do século XIX. In: Revista brasileira de história da educação. Campinas/São Paulo: Autores Associados, $\mathrm{n}^{\circ}$. 20, 2009, p. 80-121 (no prelo).

Nem tudo é valentia ou vadiagem: práticas culturais e usos de símbolos de civilidade por escravos, forros e mestiços na Província do Maranhão Oitocentista. In: GALVES, Marcelo Cheche, COSTA, Michael P. Revista outros tempos. São Luís: UEMA, 2007, vol. 04 ISSN 1808-8031. p. 1636. Disponível em: www.outrostempos.uema.br

Uma abordagem sobre a história da escolarização do negro. In: ROMÃO, Geruse. História da educação dos negros e outras histórias. Brasília: Ministério da Educação, Secretaria da educação continuada, alfabetização e diversidade, 2005.

ELIAS, Norbert. O processo civilizador: uma história dos costumes. Rio de Janeiro: Jorge Zahar Editor, 1990.

FARIA FILHO, L. M. de. Instrução elementar no século XIX. In: LOPES, Eliane Marta Teixeira; FARIA FILHO, Luciano Mendes de; VEIGA, Cynthia Greive. 500 anos de educação no Brasil. $3^{\circ}$ ed. São Paulo: Autêntica, 2007.

FIGUEIREDO, Luciano. Mulheres nas Minas Gerais. In: DEL PRIORE, Mary; Lucy Murray (org.). História das mulheres no Brasil. 9 ed. São Paulo: Contexto, 2007.

GINZBURG, Carlo. Mitos, emblemas, sinais: morfologia e história. 2 ed. São Paulo: Companhia das Letras, 2003.

HÉBRARD, Jean. A escolarização dos saberes elementares na época moderna. Revista TEORIA E EDUCAÇÃO, Porto Alegre, nº. 2, 1990. 
LOURO, Guacira Lopes. Mulheres na sala de aula. In: DEL PRIORE, Mary; Bassanessi (org.). História das mulheres no Brasil. 9 ed. São Paulo: Contexto, 2007.

MARQUES, A. César. Dicionário histórico geográfico da província do Maranhão. Edição fac-similar. Rio de Janeiro: Fon-fon e Seleta, 1970.

SCHWARTZ, Stuart B. Segredos internos: engenhos e escravos na sociedade colonial, 1550-1835. $3^{\circ}$ reimpressão. São Paulo: Companhia das Letras, 2005

VAINFAS, Ronaldo (org.). Dicionário do Brasil Imperial- 1822-1889. Rio de Janeiro: Objetiva, 2002.

VINCENT, Guy; Lahire Bernard; THIN, Daniel. Sobre a história e a teoria da forma escolar. Educação em Revista, Belo Horizonte, nº 33, jun., 2001.

VIVEIROS, J. de. Apontamentos para a história da instrução pública e particular do Maranhão. REVISTA DE GEOGRAFIA E HISTÓRIA. São Luís/MA: IBGE, ANO IV, dezembro de 1953.

\section{FONTES}

\section{Manuscritos - Arquivo Público do Estado do Maranhão}

Códices

Livro de Registro de Correspondência do Presidente da Província com Diversas Autoridades, $\mathrm{n}^{\circ} 101,1867-1870$.

Primeiro Caderno de Recenseamento da População da Cidade de São Luís do Maranhão, Maranhão, 20 de maio de 1855, nº 1701.

Documentos avulsos (ofícios e relatórios)

Secretaria do Governo. Diretor do Asilo de Santa Teresa /Presidente da Província do Maranhão. APEM, Cxs. APEM, Avulsos, Cx.1855-1870.

Relatório da Sociedade Manumissora Vinte e Oito de Junho ao Presidente da Província do Maranhão em 04 de dezembro de 1871. Sociedades/ Presidente da Província do Maranhão. APEM, Avulsos,Cx. 1869-1889.

Coleções de leis, portarias e regulamentos da província do Maranhão (impressos) Biblioteca Pública Benedito Leite (MA)

Contrato feito em 8 de maio de 1855 que determina as responsabilidades do governo da província do Maranhão em relação ao engajamento de colonos. 
Lei Provincial $\mathrm{n}^{\circ} 106$ de 27 de agosto de 1841, autorizando o Presidente da Província a despender até a quantia seis contos de reis anuais com a introdução de colonos estrangeiros.

Lei Provincial $\mathrm{n}^{\circ} 115$ de 1 de setembro de 1841. A prova o estatuto do Liceu e outras providências acerca do ensino público.

Lei $\mathrm{n}^{\circ}$ 267, de 17 de dezembro de 1849. Reorganiza a instrução pública desta província e condiciona o ordenado dos professores à quantidade de alunos.

Lei $\mathrm{n}^{\mathrm{o}} 381$ de 30 de junho de 1855. Aprova o contrato feito pelo governo da província com o empresário da Colônia Agrícola Santa Thereza na parte relativa a criação da cadeira de Primeiras Letras.

Lei ${ }^{\circ} 408$ de 18 de julho de 1856. Eleva o número de educandos artífices e de educandas do Asilo de Santa Teresa e manda admitir na Casa dos Educandos Artífices três indígenas menores.

Lei ${ }^{\circ} 624$ de 1861 . Autoriza a mandar estudar agricultura três estudantes.

Lei $n^{\circ}$ 666, de 7 de julho de 1863. Autoriza o presidente da Província mandar estudar na Europa os jovens Horácio Tribuzzi e Joaquim Belfort Sabino.

Lei n 769 de 27 de junho de 1866. Autoriza o presidente da Província a mandar estudar na Europa Francisco Peixoto Franco de Sá.

Lei ${ }^{\circ} 1071$ de 4 de julho de 1874. Manda remeter três surdos mudos para o Rio de Janeiro.

Lei $\mathrm{n}^{\circ} 1091$, de 17 de julho de 1874 . Aprova o regulamento da instrução pública.

Portaria de 28 de junho de 1860. Altera o regulamento da Escola de Aprendizes Agrícolas.

Portaria de 22 de julho de 1872 - Aprova o Estatuto da Sociedade Manumissora 28 de julho.

Regulamento de 16 de janeiro de 1855. Organiza o Asilo de Santa Teresa.

Regulamento de 2 de fevereiro de 1855. Reorganiza e regula o ensino elementar e secundário.

Regulamento de 10 de dezembro de 1858. Cria a escola de aprendizes agrícolas.

Regulamento da escola de aprendizes agrícolas de 3 de agosto de 1859. 